A Journal of Culture, English Language, Teaching \& Literature

ISSN 14143320 (Print), ISSN 2502-4914 (Online)

Vol. 17 No. 2; December 2017

Copyright ( () Soegijapranata Catholic University, Indonesia

\title{
Reduplication of Mongondow Language
}

\section{${ }^{1}$ Donal Matheos Ratu, ${ }^{2}$ Mister Gidion Maru}

${ }^{1,2}$ English Department, Faculty of Languages and Arts,

Universitas Negeri Manado, Manado, Indonesia

email: 1donalratu@unima.ac.id, ²mrhekang@yahoo.com

Received: 02-11-2017

Accepted: 04-12-2017

Published: 15-12-2017 


\title{
Reduplication of Mongondow Language
}

\author{
${ }^{1}$ Donal Matheos Ratu and ${ }^{2}$ Mister Gidion Maru \\ 11donalratu@unima.ac.id, ${ }^{2}$ mrhekang@yahoo.com \\ 1,2 English Department, Faculty of Languages and Arts, Universitas \\ Negeri Manado, Manado, Indonesia
}

\begin{abstract}
This study aims at describing the reduplication of Mongondow and its meanings. The method used in this research is descriptive method in taxonomy that is an elaboration by classifying elements of language according to hierarchical relationship. Data were obtained through primary and secondary data sources. Primary data were collected through interviews with five informants chosen from Tutuyan region, of Tombolikat village, who are active speakers of Bolaang Mongondouw language. Secondary data were gathered through a text study. The results show that the formation of Mongondow words can be done by reduplication, either whole or complete reduplication and partial reduplication consisting of reduplication of deletion on the word base, reduplication of initial syllable and affixed reduplication. The reduplication of Mongondow language has the following meanings: (1) to declare uncertain plurality, (2) to declare reciprocal meaning, (3) to declare collective and distributive meaning, (3) to declare command or advice, (4) to declare the tool, (5) to declare the place (6) to declare about superlative, (7) to declare about more quality, and (8) to state the meaning of an action done with pleasure or comfort.
\end{abstract}

Key words: reduplication, language, Bolaang Mongondouw

\begin{abstract}
Abstrak: Studi ini bertujuan menggambarkan reduplikasi Bahasa Mongondow dan maknanya. Metode yang digunakan adalah deskriptif dalam taksonomi berupa elaborasi dengan mengklasifikasikan elemen - elemen bahasa sesuai dengan hubungan hierarkisnya. Data didapatkan dalam bentuk sumber primer dan sekunder. Data primer diperoleh melalui wawancara dengan lima informan kunci dari wilayah Tutuyan, dalam hal ini desa Tombolikat. Hal ini dilakukan karena sebagian besar penutur di wilayah Tombolikat masih aktif menggunakan Bahasa Mongondow. Data sekunder dikumpulkan melalui studi pada teks yang telah dikumpulkan. Hasil penelitian menunjukkan bahwa pembentukan kata - kata
\end{abstract}




\begin{abstract}
Mogondow dapat dengan cara reduplikasi baik secara keseluruhan maupun sebagian yang terdiri dari reduplikasi penghilangan akhir kata, reduplikasi suku kata awal dan reduplikasi imbuhan. Makna reduplikasi bahasa mongondow antara lain; 1) menyatakan jamak yang tidak tentu, 2) menyatakan makna resiprokal, 3) menyatakan makna distributive dan kolektif, 4) menyatakan perintah atau saran, 5) menyatakan tempat atau alat, 6) menyatakan makna superlative, 7) menyatakan kualitas, dan 8) menyatakan aksi yang dilakukan dengan senang hati
\end{abstract}

Kata kunci: reduplikasi, mongondow, deskriptif, makna, pembentukan kata

\title{
INTRODUCTION
}

Culture of a region is strongly influenced by its language users. Regional language or also known as the mother tongue, is a symbol of the identity of a region, community, family, and environment. Local language users can also create a warmth of familiarity, as Todd (in Alwasilah,1993, p. 27) puts it "bahasa ibu diasosasikan dengan perasaan, kehangatan, keakraban dan spontanitas." Cultural preservation is very important, as stated in the UUD 1945 about language preservation and maintenance. UUD 1945 mandates that "daerahdaerah yang mempunyai bahasa yang dipelihara oleh rakyatnya dengan baik akan dihormati dan dipelihara juga oleh negara, bahasa - bahasa itu pun merupakan bagian dari kebudayaan Indonesia yang hidup".

Bolaang Mongondow regency is one of the areas in North Sulawesi that has its own local language. The Bolaang Mongondow Language Speakers in 2011 are estimated to amount of around 400,000, scattered in a number of Bolaang Mongondow district settlements, Kota Mobagu, East Bolaang Mongondow, South Bolaang Mongondow. Mongondow language is actively used in communications among fellow members of the community and becomes a local content in teaching local languages in schools that exist in the majority areas of Mongondow language users. This language is a marker of the identity of existence as a socio-cultural group and a distinctive feature that distinguishes it from other social groups in North Sulawesi.

Language can be studied from several aspects. One of the most important aspects of the study in language is reduplication or word repetition. Samsuri $(1985$, p. 66) asserts that reduplication is a frequent process in the language of the world and has certain types. Similarly, Verhaar states, that reduplication is commonly found in languages in Southeast Asia including Indonesia (1988, p. 63). Reduplication can be used in the language 
to express things of a plural nature, explanation, or intensity that goes on and on (Sapir, 1994, p. 98); this applies also to Mongondow language. Thus, reduplication is one form in the language of a large role. Some of the above statements indicate that reduplication needs serious attention including reduplication in Mongondow language.

Another reason that is quite essential is the greater influence of Malay Manado on Mongondow. In communicating activities, the community began mixing the use of Malay Manado language in Mongondow. In its usage pattern, the Bolaang Mongondow language participates in Indonesian language especially in formal (formal) situations such as lectures, sermons and meetings in the villages. Not infrequently Mongondow language is used with the intent to emphasize or explain something that is considered important.

Although on the other hand also used Manado Malay language, the occurrence of things like this is because the people of Indonesia are multilingual, which means that the people use more than one language (Mackey, 1970, p. 12). According to Mulyana, Indonesian and other languages in Indonesia as one group, has also become the basis for researching this issue $(1982$, p. 17). He further said that the Austronesian languages have a similar reduplication system. This statement implies that both Bolaang Mongondow and Indonesian have similarities in the form of reduplication. This view is the basis for researching the such problem in Mongondow.

From the results of initial observations, researchers got a description of the reduplication of Bolaang Mongondow language, for example: (1) tondok = fence $(\mathrm{N})$ tondo-tondok $=$ fences-fences $(\mathrm{N}),(2)$ pomasol $=$ hoe $(\mathrm{V})$ pomaso-masol $=$ hoe-hoe, (3) anto? - lots = moanto moanto? = at most. The examples show the reduplication in Bolaang Mongondow. Example (1) shows, that the reduplication of the word base produces an indeterminate plural meaning. Then, example (2) is a reduplication that gives the meaning of qualitative intensity. Finally, example (3) is the reduplication, which shows the most meaning. Nevertheless, these examples and explanations have not represented the matter of reduplication in Mongondow language for detail. From the reasons above, researcher is interested to raise the issue of reduplication.

The problem of reduplication in Mongondow language, according to the researcher, has been never conducted by anyone. That is why researcher tried to reveal the reduplication of Bolaang Mongondow language since the problem of language shift is so strong that it is predicted that one day this will 
lead to language death if it does not get serious attention from the people who have the language. As a regional language preservation effort, the government has also programmed the teaching of regional languages in schools, nowadays known as Muatan Lokal (Mulok). This is one of many educational programs in which the content of the delivery media is linked to the surrounding natural environment and the culture and needs of regional development that need to be taught to the students (Ibrahim \& Karyadi, 1996). Thus the local language has been contained in the school curriculum. In this case the curriculum will be used is KBK curriculum. CompetencyBased Curriculum (Kurikulum Berbasis Kompetensi) is a tool of plans and arrangements on the competencies and learning outcomes that learners, assessments, teaching and learning activities need to achieve, and the empowerment of educational resources in the development of school curricula.

Based on the existing descriptions, the researcher conducted a research with the object of Bolaang Mongondow language study with scientific paper in the form of thesis entitled: "Reduplication of Mongondow Language (a contribution toward Indonesian Learning). Within this context, this research paper addresses the question how the form and meaning of reduplication in Mongondow language are. Therefore, the paper is intended to describe the form of Mongondow language reduplication and describe its meanings.

\section{THEORETICAL BASES}

\section{A. Geographical location}

Bolaang Mongondow is located on the north peninsula of Sulawesi island extending from west to east and flanked by two other districts, namely Gorontalo (now a province) and Minahasa. Geographically this area lies between 100.30 " LU and 0020" as well as between 16024'O "BT and 17054'0" BT. The north is bounded by the sea of Sulawesi and the south with the Maluku Sea.Bolaang Mongondow is a landscape that stands alone and selfgoverning and is still a closed area until the end of the 19th century. Foreign relations are merely trade relations held through contracts with the ruling kings of the time. With the influx of foreign governments (Dutch) around 1901, the administrative area includes Onderafdeling Bolaang Mongondow which includes the Binatuna landschap, Bolaang Uki, Kaidipang from Afdeling Manado. 
212 Celt: A Journal of Culture, English Language Teaching \& Literature, Volume 17, Number 2, December 2017, pp. 208 - 229

Coastal boundary with Gorontalo region by two rivers, i.e. north of Andagile river and south by Taludaa river. With the Minahasa area also two rivers that are north of the river Poigar and in the south by the Buyat river. The widest field is about $66 \mathrm{~km}$ distance between the river Poigar and the cape of Flesko. The narrowest one is between the village of Sauk in the north and the village of Popodu in the south.

The leader of the Bolmong community in the past was called Bogani which is now in Bolaang Mongondow area, there is a Bogani statue located in Kotabangon village of Kotamobagu sub-district.

\section{B. Definition of morphology}

To know the morphology definitions, the following are some opinions from linguists. First, Kridalaksana states that morphology is a linguistic field that studies the morphemes and their combinations (1983, p. 11). Second, Badudu states morphology is the science that talks about the morpheme how morpheme forms (1983, p. 66). Third, Keraf states morphology is a study of the ins and outs of the word and the influence of changes in the form of the word to the class and meaning of the word, or in other words can be said that morphology learn the ins and outs of words and changes in the form of words that is, both grammatical and semantic functions (1984, p. 51). From all the definitions described above, it can be concluded that morphology is the study of the morpheme and its function of both grammatical and semantic changes. Each unit of words in language has a form and body. The following linguist opinions about the definition of word are quoted.

According to Ramlan the word is the smallest free unit or any one free unit is a word (1987, p. 33). Meanwhile, Chaer argues that the word is a unit of language that has one sense in other words is a series of letters flanked by two spaces and has meaning (1994, p. 62). So, the word is a free form that stands alone. In Indonesian the word form can be divided into two parts, (1) Single or simple form is a form or unit that has a smaller unit again, and (2) The complex form is the form of a unit that consists of units that are smaller again, Ramlan (1987, p. 28).

\section{Definition of reduplication}

In traditional grammar, repeated words are often called reduplications. According Ramlan the process of repetition or reduplication is the repetition of grammatical units either entirely or partially either with variations of the phoneme or not (2001, p. 63). Meanwhile long before Kridalaksana states 
that reduplication is a process with the result of repeating the language units such as phonological or grammatical tools (1986, p. 143).

In contrast, Chaer states that reduplication is a morphemical process that repeats the basic form, either whole, partially, or by sound change (2002, p. 182). From some opinions mentioned above can be concluded, that reduplication is the process of repeating the form whether the shape is intact or some even sometimes phonemic changes. According to Verhaar, reduplication occurs in many languages of the world in connection with this statement (1988, p. 63). Keraf states that to examine reduplication in a language should be viewed carefully and adapted to the conditions of the language related (1987, p. 120).

\section{Function and meaning of reduplication}

According Keraf reduplication can be studied in terms of kinds, functions and meanings (1987, p. 120).

1. Kinds of repetition

Based on its kind, the form of looping in Indonesian according to Keraf (1987, p. 120) can be divided into four types:

a) Deuteronomy over the initial syllable, or also called dwipurwa. In this form of repetition, the vowels of the initial syllable are weakened and shifted to the middle position into e (pepet). For example: tatanaman> tetanaman, tatangga> tetangga, luluhur> leluhur

This deuteronomy even though is determined in Indonesian, the examples are not many.

b) Repeat of entire basic form. This is called a complete repetition. There are two kinds of repetitions, namely repetition of the basic form of the word base and called dwilingga, and a repeated basic form of word with affix.

For example: rumah> rumah-rumah, perbuatan> perbuatan-perbuatan, buah> buah-buah,kejadian>kejadian

Full replication is found in many languages, including Indonesian and highly productive. 
214 Celt: A Journal of Culture, English Language Teaching \& Literature, Volume 17, Number 2, December 2017, pp. 208 - 229

c) Next, replication occurs over all syllables, but on one lingga there is a change of sound on one or more phonemes. This kind of repetition is called dwilingga salin suara. For example: gerak-gerak> gerak-gerik, sayur-sayur> sayur-mayur, porak-porak> porak-porik

Although this form is not too much in language, but often appears in the activities of speech.

d) The fourth deuteronomy is repetition with affix, both on the first part and on the second part. This type of replication is called repetition with affix. For example: bermain-main, memukul-mukul, berpukul-pukulan, main-mainan

Seeing this description means that a complete initial syllable repetition, repetition of phonemic changes and replicated affixes are the kinds of repetitions that are often found in the Indonesian language.

2. Function

Determining the function of the repeated word here will be very difficult, because according to Keraf, the functions and meanings are tightly connected, cannot be separated from each other (1987, p. 120). But if we only see the function as a tool for forming the word type, then it can be said that the repetition of a word will decrease the same type of word as if it were not repeated: mainan, the same type as main-mainan, tali is the same as tali temali and so on. So it can be said that the function leads to the kind of word produced after the word is repeated.

\section{Meaning}

More clearly we can classify based on the meaning, but there is no denial in it already established the function of repetition. Or it can be said in another way, that it has a function to produce a certain meaning (Keraf, 1987, p. 121). Although here the different functions of the meaning are difficult to recognize, but in general the distinction is clearly visible.

The meaning that can be supported by the repetition that according to Keraf (1987, p. 121) is:

a) Repetition first of all means a lot that are indeterminate. To declare a lot that are determinate, the Indonesian language does not require 
a reshape. Consider the following example: Di padang terdapat 3 ekor kuda (a lot that are determinate), Kuda-kuda itu berkejar-kejaran (a lot that are indeterminate). Another example is: Ayah membelikan saya sepuluh buah buku (a lot that are determinate) and Buku-buku itu telah kusimpan dalam lemari (a lot that are indeterminate).

b) Besides a lot that are indeterminate, the form of repetition contains another meaning, which is bermacam-macam (diverse). For example: tanam-tanaman $=$ many and diverse plants, buah-buahan $=$ many and diverse fruits

The repeated word in this case is usually completed with the suffix -an.

c) Another meaning that can be derived from a word that resembles or imitation of something. For example: kuda-kudaan, anak-anakan, orang-orangan

d) Close to the third meaning is to weaken the meaning, in this case can be interpreted with agak. For example: Apa-apa yang dilihatnya diambilnya, Sifatnya kekanak-kanakan, Orang itu sakitsakitan, Gadis itu kemalu-maluan melihat pemuda itu.

e) Expressing the intensity, either the intensity of quality (qualitative intensity), both about quantity (quantitative intensity), or about frequency (frequency intensity). For example: Pukullah kuat-kuat, Belajarlah segiat-giatnya, Gunung itu yang setingg-tingginya di pulau Jawa.

i) Quantitative intensity. For example: kuda-kuda, rumah-rumah. buah-buah, anak-anak, etc.

ii) Frequency Intensity. For example:m Ia menggeleng-gelengkan kepalanya, Ia mondar-mandir saja sejak tadi.

f) Deuteronomy on the verb can decrease the meaning of mutual, or reciprocal work (each other). For example: Terjadi tawar-menawar dalam proses jual beli, Ia berpukul-pukulan dengan si Dul, Keduanya bersalam-salaman. Another example is: Dalam perkelahian itu terjadi tikam-menikam antara kedua orang itu. 
216 Celt: A Journal of Culture, English Language Teaching \& Literature, Volume 17, Number 2, December 2017, pp. 208 - 229

g) The repetition of the numerical word has a collective meaning: dua-dua, tiga-tiga, lima-lima, and others.

\section{E. Form of reduplication}

Based on the way of repeating the basic form, repetition can be classified into four groups:

1. The entire repetition

The entire repetition is the repetition of all basic forms, without any phonemic changes and not in combination with the affixing process. For example: sepeda $=$ sepeda-sepeda, buku = buku-buku, kabaikan = kabaikan-kabaikan

Based on the above example it can be said, that the whole iteration underlines that the whole existing word is repeated.

\section{Partial repetition}

Partial repetition is a partial repetition of its basic form. Almost all the basic forms of this type of repetition are complex forms. A single form is a word lelaki formed from the basic laki, also tetamu being formed from the basic form tamu, beberapa which is formed from the berapa, pertama-tama formed of the basic form pertama, and segala-galanya from the basic form segala.

The word pertama and all are singular because in the morphological sequence there is no smaller unit of the two words. Indeed, in addition to the first word, there is word utama, but the two words cannot be inserted into a single morphological sequence. Although both have a form affinity, both of which contain the element tama, but they have no coherence of meaning so that the word pertama is defined as a morpheme, the word utama as one morpheme as well.

\section{F. Function of Reduplication}

There is process of repetition which serves to change the class of words, and there is repetition which does not. In repeated words like karangmengarang, cetak-mencetak, potong-memotong, jilid-menjilid, the process of repetition has the function of forming the nominal word of the verb, and also in the function of repeated words such as sekuat-kuatnya, the process of repetition serves as the former of the adverb from the adjective, but on the 
repeated words binatang-binatang, rumah-rumah, pembangunan-pembangunan, kuda-kudaan, anak-anakkan, berteriak-teriak, memukul-mukul, pandang-memandang, surat-menyurat, cepat-cepat, kecil-kecil, the process of repetition does not change the word class.

\section{G. Meaning of Reduplication}

The process of repetition has several meanings:

1. Stating the meaning of 'many'.

Let us compare the word rumah to the word rumah-rumah in two sentences such as: Rumah itu sudah sangat tua, and Rumah-rumah itu sudah sangat tua. The word rumah in the phrase 'Rumah itu sudah sangat tua' declares 'sebuah rumah', while the word 'rumah-rumah' in the sentence 'Rumah-rumah itu sudah sangat tua' declares 'banyak rumah'. This is the same with: binatang-binatang = banyak binatang, pembangunanpembangunan = banyak pembangunan. $($ Keraf, 1987, p. 121)

2. State the meaning of 'many'

In contrast to the meaning mentioned above, here the meaning of 'banyak' is not related to the basic form, but rather relates to the "explained" word. The word 'explained' at the phrase level occupies a function as a central element, for example the word 'rumah' in rumah besar besar. Clearly, the repetition of the 'besar-besar' expresses the meaning of 'banyak' to the 'explained' word, in this case the word 'rumah'.

Other examples, are: Mahasiswa yang pandai-pandai mendapat beasiswa, Mahasiswa itu pandai-pandai, Pohon yang rindang-rindang itu pohon beringin, Pohon di tepi jalan itu rindang-rindang.

3. Stating the meaning of 'unconditional' (Keraf, 1987, p. 123)

Example: duri-duri diterjang = 'meskipun duri diterjang', darah-darah diminum = 'meskipun darah diminum'

4. State the meaning 'that resembles what is on the basic form'.

In this case the repetition process combines with the change process of affix -an. For example: kuda-kudaan: 'that resembles 'kuda', gununggunungan: like 'gunung'. Similarly, sepeda-sepedaan, mobil-mobilan, orang- 
218 Celt: A Journal of Culture, English Language Teaching \& Literature, Volume 17, Number 2, December 2017, pp. 208 - 229

orangan, kereta-keretaan, and so on. The meaning of 'resembling' is also present in repeated words such as: kebarat-baratan = resembling 'western people', kemuda-mudaan = resembling 'the youth'.

5. Stating the meaning of 'action on the basic form done repeatedly'.

Example: berteriak-berteriak = 'screaming for several times, memukul-mukul = 'hitting for several times', memetik-metik ='plucking for several times', menyobek-nyobek ='ripping off for several times' (Ramlan, 2001, p.181).

In addition, the meaning, the actions which are mentioned in the basic form done repeatedly and this is numerous and often found in Indonesian language. For example, to declare the meaning of 'the act in which its basic form is done casually, intentionally, or with pleasure', the following samples are found: berjalan-jalan = 'walking with pleasure, membaca-baca = 'reading with pleasure', tidur-tidur = 'sleeping with pleasure' or 'not really sleeping.'

Meanwhile, to declare the meaning of 'action on the basic form is done by two parties and mutual concern'. In other words, the repetition expresses the meaning of 'mutual'. Examples are: pukul-memukul = 'hitting each other', pandang-memandang = 'looking at each other' (Ramlan, 2001, p. 182). Such meaning exists only in the repetition of the verb, stating that it is reciprocal (Keraf, 1987, p. 123).

\section{METHODOLOGY}

This study aims at describing the reduplication of Mongondow language which contributes to the teaching of regional languages in Bolaang Mongondow schools. To obtain data related to the above problems, the researcher uses descriptive-qualitative research method. That is, in descriptivequalitative research, data collected in the form of words, images, not numbers (Moleong, 1991, p. 6). Data were obtained from primary and secondary data source. Primary data were got from interview to five informants chosen from Tutuyan, particularly Tombolikat village, considering the majority of people in Tombolikat still actively use Bolaang Mongondouw language. Secondary data was taken through collected text study. Data collection techniques used in this study refer to the methods or techniques offered by Mahsun (2005, pp. 126-135), namely: Listening Method and Direct Talking Method. 
To avoid errors or mistakes of data that have been collected, it is needed to check the validity of data. Checking the validity of the data is based on the criterion of degree of trust (credibility) with triangulation technique (Moleong, 2004). Triangulation is a technique of checking the validity of data based on something outside the data for checking purposes or as a comparison of existing data (Moleong, 2004). Triangulation used is triangulation with source, data of result of text study and interview result. The stages of data analysis refer to the two methods offered by Mahsun (2005, pp. 117-122), namely Intralingual Method, and Extraordinary Padan Method

\section{RESULT}

\section{A. The form and meaning of reduplication of Mongondow Language}

Based on the results of existing data analysis, Mongondow's form of reduplication is having: (1) complete or whole reduplication, reduplication of the coda on the word base, (3) reduplication of initial syllables, (4) reduplication affixed. The following are the details about each.

\section{Complete or whole reduplication}

Whole or full reduplication in Mongondow language can be found in the verbs, nouns, adjectives, pronouns, adverbs, and numeric words. Examples are: $/$ garab/ = throw, garab-garab = 'lempar-lempar'. The context can be imilar to: [ba ko ontoyan pira garap-garap kayu tana?a] - Supaya kelihatan baik, lempar-lempar kayu ini. Other examples are: (a) / mea?/

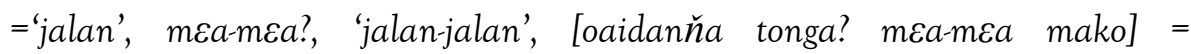
Pekerjaannya hanya jalan-jalan terus.; (b) /kayuon/ 'hutan', kayuon-kayuon 'hutan-hutan', [mo anto? pa kayuon-kayuon kon lipu?] = Masih banyak hutanhutan di kampung.

a) Full reduplication of adjective.

Example:

/dalom/ 'dalam', dalom-dalom 'dalam-dalam', [parigi kon bulut dalomdalom] $=$ Sumur di pegunungan dalam-dalam.

b) Full reduplication of pronouns

Examples: 
220 Celt: A Journal of Culture, English Language Teaching \& Literature, Volume 17, Number 2, December 2017, pp. 208 - 229

(i) /iko/ 'kau', iko-iko 'kau-kau', [iko-iko don ten tunduon momalui keňia] = Kau-kau saja yang ditunjuk menggantikan dia

(ii) /sia/ 'dia', sia-sia 'dia-dia', [dika sia-sia turus ten ogean doit] = Jangan dia-dia terus yang diberikan uang.

c) Full redupliction of numeric words

Examples:

(i) /tolu/ 'tiga', tolu-tolu 'tiga-tiga', [aka tumo?ot tolu-tolu] = Kalau mau masuk harus tiga-tiga.

(ii) /topili?/ 'sedikit', topili-topili? 'sedikit-sedikit', [biar topili? - topili? nokouli? dait] = Walau sedikit-sedikit semua dapat.

d) Full reduplication of adverbs

Example:

/bagu/ 'baru', bagu-bagu 'baru-baru', [bagu-bagu na?a sia nobui ko lipu] = Baru-baru ini dia pulang ke kampung

2. Reduplication with deletion of coda in the base word

a) Reduplication with deletion of coda in verb

Examples:

(i) /gakod/ 'ikat', gako-gakod 'ikat-ikat', [tali tana?a po gako-gakod kon sapi] = Tali itu untuk ikat-ikat sapi.

(ii) /giris/ 'iris', giri-giris 'iris-iris', [sosilad tatua poyiri-yiris kon tEa?] = Pisau itu untuk mengiris-ngiris ikan.

b) Reduplication with deletion of coda in noun

(i) /baloy/ 'rumah', balo-baloy 'rumah-rumah', balo-baloy tatua moyo gaga. = Rumah-rumah itu bagus-bagus.

(ii) /tondok/ 'pagar', tondok-tondok 'pagar-pagar', [tondo-tondok tatua warna mopura] = Pagar-pagar itu berwarna merah.

c) Reduplication with deletion of coda in adjetives 
(i) /ropot/ 'kuat', ropo-ropot 'kuat-kuat', [mo sia taua mo ropo-ropot majoy] = mereka itu kuat-kuat.

(ii) /darag/ 'kuning', dara-darag 'kuning-kuning', [sia tatua no dara-darag] = Dia itu kuning-kuning.

d) Reduplication with deletion of coda in numeric words

(i) /opat/ 'empat', opa-opat 'empat-empat', [mosia opa-opat dait nobali' guru] = Mereka empat-empat menjadi guru.

(ii) /baroy/ 'banyak', baroy-baroy 'banyak-banyak', [aka mo bogoy musti baroy-baroy] = Kalu memberi harus banyak-banyak.

e) Reduplication with deletion of coda in adverbs

(i) /bio?/ 'diam', bio-bio? 'diam-diam', [aka tu mo'od baloy mosia bio-bio?] = Kalau masuk rumah mereka diam-diam.

(ii) /ampal/ 'pelan', ampa-ampal 'pelan-pelan', [aka mo cerita ampaampalai pa] = Kalau bercerita pelan-pelan.

3. Reduplication in initial syllable

a) Reduplication in initial syllable in numeric words

(i) /tobatu/ 'satu', totobatu 'satu-satu', [aka mo gama ko kombiloy totobatu?] = Kalau mau ambil mangga satu-satu.

(ii) /dewa/ 'dua', dedewa 'dua-dua', [aka tumo?ot baloy dedewa] = Kalau masuk rumah dua-dua.

4. Reduplication with prefixes

a) Verb Base form

prefix mo-

(i) tarap/ 'lihat', motara-tarap 'melihat-lihat', [sia tatua motara-tarap mangoy] = Orang itu melihat-lihat saya.

(ii) mais 'tulis', momai-mais 'menulis-nulis', [o aidannya toya? momai-mais kon buk] = Kerjanya hanya menulis-nulis di buku.

prefix moN 
222 Celt: A Journal of Culture, English Language Teaching \& Literature, Volume 17, Number 2, December 2017, pp. 208 - 229

(i) /dagum/ 'jahit', mondagu-dagum 'menjahit-jahit', [olat pa topili' aku oi mondagu-dagum lambuy tana?a] = Tunggu sebentar, saya mau menjahitjahit baju ini.

(ii) /pahis/ 'tulis', momahi-mahis 'menulis-nulis', [olat pa topili? aku oy momahi-mahis ko buk tana?a] = Tunggu sebentar, saya mau menulisnulis buku ini.

prefix po-

(i) /garab/ 'lempar', pogara-garap 'melempar-lempar', [o aidanmu toya? bi pogara-garab bango?] = Pekerjaan kamu hanya melempar-lempar kelapa.

(ii) /radat/ 'gosok', porada-radat 'menggosok-gosok', [ki papa porada-radat lima] = Ayah menggosok-gosok tangan.

b) Noun Base Form

(i) /pasol/ 'cangkul', pomaso-masol 'mencangkul-cangkul', [o aidanňa toya? pomaso-masol kon goba?] = Kerjanya hanya mencangkul-cangkul di kebun.

(ii) /simpat/ 'sapu', monimpa-nimpat 'menyapu-nyapu', [o aidønn̆a tona? bi monimpa-nimpat kobonu baloy] = Kerjanya hanya menyapu-nyapu di dalam rumah.

c) Adjective Base Form

(i) /yayu?/ 'jauh', moyayu-yayu? 'menjauh-jauh', [dika moyayu-yayu? aka mea?] = Jangan menjauh-jauh kalau pergi.

(ii) /ompa?/ 'pendek', moumpa-ompa? 'paling pendek', intau tatua moumpa-umpa? mayoy = Orang itu yang paling pendek.

d) Numeric Word Base Form

/anto?/ 'banyak', moanto-anto? 'paling banyak', [kon baloyn̆a moantoanto? intau $=$ Di rumahnya paling banyak orang.

5. Reduplication with Infix

a) Verb Base Form Reduplication

infix -um- 
/gotup/ 'meletus', gumotu-gotup 'sudah meledak-ledak', [bulud tatua gumotu-gotup] = Gunung itu meletus-letus.

infix -im-

(i) /tindok/ 'berdiri', timindok-tindok 'sudah berdiri-diri', [intau tatua timindok-tindok ko muka baloy] = Orang itu sudah berdiri-diri di depan rumah.

(ii) /kosiy/ 'tertawa', kimosing-kosing 'sudah tertawa-tawa', [bagu dolodolom intau tatua kimosing-kosing] = Masih pagi-pagi orang itu sudah tertawa-tawa.

infix -in-

(i) lopot/ 'potong', ilopo-lopot 'dipotong-potong', [bango' tatua ilopo-lopot nobali de?Ewa] = Kelapa itu dipotong menjadi dua.

(ii) llosi/ 'belah', linosi-losi 'dibelah-belah', [kasubi tatua linosi-losi i papa] = Ubi itu dibelah-belah oleh papa.

combination between in $+u m$, -inum-

(i) /gakod/ 'ikat', ginumakod-gakod 'sudah diikat-ikat', [intau tatua ginumakod-gakod sandiri] = Orang itu mengikat-ngikat dirinya sendiri.

(ii) /kuak/ 'teriak', kinumuak-kuak 'sudah berteriak-teriak', [ki fikri kumuak-kuak no ko?ontong kon ulag] = Si Fikri sudah berteriak-teriak melihat ular.

b) Adjective Base Form

infix -um- that can be placed in adjectives

(i) Moben/ 'besar',lumoben-loben 'menjadi semakin besar', [sio?olňa totok lumobe-loben] = Kakinya semakin menjadi besar.

(ii) /limbuy/ 'bulat', lumimbu-linzbuy 'menjadi semakin bulat', [biapong tatua pi nomia lumimbu-limbuy] = Bakpao itu dibuat menjadi bulat.

6. Reduplication with suffix

a) Verb base form

suffix -don 
224 Celt: A Journal of Culture, English Language Teaching \& Literature, Volume 17, Number 2, December 2017, pp. 208 - 229

(i) /litu/ 'duduk', litu-litudon 'duduk-duduklah', [litu-litudon kon buta?] = Duduk-duduklah di tanah.

(ii) /siug/ 'tidur', siug-siugdon 'tidur-tidurlah', [siug-siugdon kon tu?otku] = Tidur-tidurlah di kamarku.

(iii) /kaday/ 'pegang', kaday-kadaydon 'pegaang-peganglah', [kaday-kadaydon limaku] = Pegang-peganglah tanganku.

Suffix $-p a$

(i) /gitog/ 'kucak', gito-gitokpa 'kucak-kucaklah', [gito-gitokpa lambuy tatua bamobali' mo budo] = Kucak-kucaklah baju itu supaya menjadi putih.

(ii) /bakut/ 'bungkus', baku-bakutpa 'bungkus-bungkuslah', [baku-bakutpa kacay minta taňiun] = bungkus-bungkuslah kacang itu.

(iii) /luai/ 'keluar', luai-luaipa 'keluar-keluarlah', [lua-luaipa moiko ambe koňion] = Keluar-keluarlah kalian di situ.

suffix -an

(i) /litu/ 'duduk', litu-lituan 'tempat duduk', [awas pakonion si litu-lituan bi' guraya nion] = Keluar dari situ sebab ini tepat duduk orang tua.

(ii) /tiug/ 'tidur', tiu-tiugan 'tempat tidur', [sia motiug kon tiu-tiugan tatua] = Dia tidur di tempat tidur itu.

suffix $-a i$

(i) /inalap/ 'ambil', inalap-inalapai 'ambil-ambilkan (kemari)', [inalapinalapai pindan tatua] = Ambil-ambilkan piring itu.

(ii) /radat/ 'gosok', rada-radatai 'gosok-gosokkan', [rada-radatai pa sianku takin lana buta] = Gosok-gosokkan perutku dengan minyak tanah.

b) Adjective base form

Suffixes that can be placed:

(i) /lantud/ 'tinggi', lantu-lantudai 'tinggi-tinggikan', [lantu-lantudai pa tukan tatua.] = Tinggi-tinggikan tangga itu. 
(ii) /ompa?/ 'pendek', ompa-ompa?ai 'pendek-pendekkan', [ompa-ompa?ai tali tatua] $=$ Pendek-pendekkan tali itu.

(iii) /raru?/ 'jauh', raru-raru?ai 'jauh-jauhkan', [raru-raru?ai pa kami kon bahaya] = Jauh-jauhkan kami dari bahaya.

(iv) /ropot/ 'kuat', ropo-ropotai 'kuat-kuatkan', [ropo-ropotai kami kon perjalanan] = Kuat-kuatkan kami di perjalanan.

(v) /ga'at/ 'kurang', ga?a-ga?atai 'kurang-kurangkan', [ga'a-ga'atai pa bogat tatua] = Kurang-kurangkan beras itu.

\section{Reduplication with a base form of verb with affix combination}

Ko-an

(i) /tintak/ 'angkat', kotinta-tintakan, [meja tatua kotinta-tintakan] = Meja itu dapat diangkat-angkat.

(ii) /gama?/ 'ambil', kogama-gama?an 'dapat diambil-ambil', [buyai kon paykoy tatua kogama-gama?an] = Buah di pohon itu dapat diambilambil.

Kino-an

(i) /gobi?i/ 'malam', kinogobi?-gobi?ian 'kemalam-malaman', [sia nobui ko baloy kinogobi?-gobi?ian] = Dia pulang ke rumah kemalam-malaman.

(ii) /tumbuk/ 'tusuk', kinotumbu-tumbukan 'tertusuk-tusuk', [siolña kinotumbu-tumbukan dugi] = Kakinya tertusuk-tusuk duri.

Mo-an

(i) /garab/ 'lempar', mogara-garaban 'saling lempar-lemparan', [adi? dewa tatua mogara-garaban] = Dua anak itu saling lempar.

(ii) /gakod/ 'ikat', mogako-gakodan 'saling ikat-ikatan', [adi' dewa tatua mogako-gakodan] = Dua anak itu saling ikat.

Mosi-an

(i) /ondok/ 'takut', mosiondo-ondokan 'saling menakuti', [ki fikri bo ki aygi mosiondo-ondokan] = Si Fikri dan si Anggi saling menakuti. 
226 Celt: A Journal of Culture, English Language Teaching \& Literature, Volume 17, Number 2, December 2017, pp. 208 - 229

(ii) /domok/ 'tangkap', mosidomo-domokan 'saling menangkap', [ki fikri bo ki anggi mosidomo-domokan bal] $=\mathrm{Si}$ Fikri dan si Anggi saling menangkap bola.

(iii) /bumbun/ 'timbun', binumbu-numbunan 'ditimbun-timbuni', [bubu? tatua binumbu-numbunan in batu] = Lubang itu ditimbun-timbuni bebatuan.

iN-ai

(i) /polok/ 'pendek', impolo-polokai 'dipendek-pendekkan', [bulu tatua impolo-polokai simpomiaan tondok] $=$ Bambu itu dipendek-pendekkan untuk dibuat pagar.

(ii) /bobat/ 'basah', inbobat-bobatai 'dibasah-basahi', [lambuyn̆a inbobabobatai sin mo patu] = Bajunya dibasah-basahi karena panas.

\section{B. Mongondow language reduplication in terms of meaning}

Based on the result of analysis, it is able to be stated here that the reduplication of Mongondow language in terms of meaning such as:

1. Describing uncertain plurality

a) /radat/ 'gosok', rada-radat 'gosok-gosok', [Siolku irada-radat kon siolnya] = Kakiku digosok-gosok pada kakinya .

b) /laig/ 'gubuk', lai-laig 'gubuk-gubuk', [lai-laig kon lipu? totok noanto?\} = Gubuk-gubuk di kampung banyak sekali.

2. Describing superlative degree

a) /garab/ 'lempar', mogara-garaban 'saling lempar-lemparan', [adi? dewa tatua mogara-garaban] = Dua anak itu saling lempar.

b) /domok/ 'tangkap', mosidomo-domokan 'saling menangkap', [ki fikri bo ki aggi mosidomo-domokan bal] = Si Fikri dan si Anggi saling menangkap bola.

3. Describing collective and distributive meaning

a) /tobatu/ 'satu', totobatu 'satu-satu', [aka mo gama ko kombiloy totobatu?] = Kalau mau ambil mangga satu-satu. 
b) /dewa/ 'dua', dedewa 'dua-dua', [aka tumo?ot baloy dedewa] = Kalau masuk rumah dua-dua.

4. Describing commands or advice

a) garab-garab 'lempar-lempar', [ba ko ontoyan pira garap-garap kayu tana?a] = Supaya kelihatan baik, lempar-lempar kayu ini.

b) /loboy/ 'tanam', loboy loboy 'tanam-tanam', [aka iko mea? loboylobog komintan toigu tatua] = Kalau kau pergi tanam-tanam jagung itu.

5. Describing continuous intensity

a) /garab/ 'lempar', pogara-garap 'melemparlempar', [o aidanmu toya? bi pogara-garab bango?] = Pekerjaan kamu hanya melempar-lempar kelapa.

b) /radat/ 'gosok', porada-radat 'menggosok-gosok', [ki papa porada-radat lima] = Ayah menggosok-gosok tangan.

6. Describing tools/place

a) /dujkul/ 'bërtemu', porodujku-dungkulan 'tempat pertemuan', [ko baloy tatua porodujku-dugkulan mosia] = Rumah itu tempat pertemuan mereka.

b) /rodomok/ 'berkelahi', pororodomo-domokan 'perkelahian', [mosia nodapot don ko pororodomo-domokan] = Mereka sudah sampai di tempat perkelahian.

7. Describing 'the most'

a) /lunat/ 'cantik', molunat-lunat 'paling cantik', [bobay tatua molunatlunat kon sekolahňa] = Gadis itu paling cantik di sekolahnya.

b) /loben/ 'besar', moloben - loben 'paling besar', "[intau tatua totok moloben-loben kon baloyn̆a], Orang itu yang paling besar di rumahnya.

8. Describing 'becoming more'

a) /loben/ 'besar', lumoben-loben 'menjadi semakin besar', [sio?olña totok lumobe-loben] = Kakinya semakin menjadi besar.

b) lluas/ 'lebar', lumuas:luas 'menjadi semakin lebar'. [sekolah tatua pinomia lumuas-luas] = Sekolah itu dibuat semakin menjadi luas. 
228 Celt: A Journal of Culture, English Language Teaching \& Literature, Volume 17, Number 2, December 2017, pp. 208 - 229

9. Describing meaning of action done with pleasure and comfort

a) /siug/ 'tidur', siug-siugdon 'tidur-tidurlah', [siug-siugdon kon tu?otku] = Tidur-tidurlah di kamarku.

b) /litu/ 'duduk', litu-litudon 'duduk-duduklah', [litu-litudon kon buta?] = Duduk-duduklah di tanah.

\section{CONCLUSION AND SUGGESTION}

The research concludes that Mongondow language is found to have (1) Complete or whole reduplication, (2) Reduplication of the lid on the word base, (3) Reduplication of initial syllables, and (4) Reduplicated affixed. Based on the analysis result, the reduplication in Mongondow language has meanings that (1) State the plural indeterminate, (2) State the meaning of each other, (3) State the meaning of collective and distributive Example: / tobatu / 'satu' totobatu 'satu-satu', (4) Describe command or advice, (5) Describe the continuous intensity, (6) Describe the tool / place, (7) Describe 'the most', (8) Describe 'becoming more', and (9) Describing meaning of action done with pleasure or comfort. As a conclusion, this research has shown to support the authors' argument that one day, most regional languages in North Sulawesi, especially Mongondow, will lead to a shift in language that could result in the extinction of this language. The strong influence of the presence of Manado Malay language is present in every corner of the village including Tombolikat which strongly influences the existence of Mongondow language. Therefore, it is suggested that readers, especially the younger generation people of Tombolikat should continue using Mongondow language either in formal situation or informal wherever and whenever, so that the sustainability of Mongondow language can always be maintained. The preservation of Mongondow potentially provides input or contribution to the perfection of Indonesian dictionaries which are full of vocabulary derived from regional languages in the Indonesian homeland.

\section{REFERENCES}

Badudu, J. S. (1983). Pelak-Pelik Bahasa Indonesia [The Difficulties of Indonesian Language]. Bandung: Pustaka Prima.

Chaer, A. (2002). Lingusitik [Linguistics]. Bandung: Angkasa. 
Ibrahim \& Karyadi. (1996). Pengembangan Paket Pembelajaran Muatan Lokal [The Development of Local Content Learning Packages]. Jakarta: Depdikbud.

Kembuan, et al. (1993). Struktur Bahasa Tontemboan [Structure of Tontemboan Language]. UNSRAT Manado.

Keraf, G. (1984). Tata Bahasa Indonesia [Indonesian Grammar]. Ende Flores: Nusa Indah

Kridalaksana, H. (1986a). Fungsi Bahasa dan Sikap Bahasa [Function and Attitude of Language]. Jakarta: PT Gramedia.

Kridalaksana, H. (1986b). Kelas Kata Dalam Bahasa Indonesia [Word Classes in Indonesian\}. Jakarta: PT Gramedia.

Mackey, W.P. (1970). The description of bilingualism in Fishman 1970.

Mahsun, M. S. (2005). Metode penelitian bahasa: tahapan strategi, metode dan tekniknya [Language research methods: stages of strategy, methods and techniques]. Jakarta: PT Raja Grafindo Persada.

Mulyana. (1982). Kaidah Bahasa Indonesia [Indonesian grammar rules]. Jakarta: Djambatan.

Ramlan, M. (1987). Morfologi sebagai tinjauan deskriptif [Morphology as a descriptive review]. Yogyakarta: Karyono

Ramlan, M. (2001). Morfologi: Suatu tinjauan deskriptif [Morphology: A descriptive review]. Yogyakarta: CV Karyono.

Samsuri. (1985). Analisis bahasa: Memahami bahasa secara ilmiah [Language analysis: Understanding language scientifically]. Jakarta: Erlangga.

Sapir, E. (1949). Language: An Introduction to The Study of Brace Speech. New York: Harvest Book, Harcourt \& World Inc.

Verhaar, J. W. M. (1988). Pengantar Linguistik [Introduction to Linguistics]. Yogyakarta: Gajah Mada University Press. 